UDC 338.33

JEL Classification M 21

Pozhuieva T.O.

\title{
CRISIS DIAGNOSTICS AND THE THREAT OF BANKRUPTCY RESEARCH - THE MAIN CRISIS MANAGEMENT WAY
}

\author{
Ukrainian State University of Chemical Technology, Dnipro, Ukraine
}

\begin{abstract}
The transition of Ukraine's economy is accompanied by instability and constant changes, which is known to have led to a systemic economic crisis in the country. Instability and the crisis situation in the economy negatively affects all spheres of social and economic life of the country. The activities of enterprises in a market economy are characterized by some degree of uncertainty and, accordingly, economic risk. The purpose of this article is to structure the approaches to the diagnosis of bankruptcy of the subject of management. The article substantiates that the use of predictive values of financial indicators obtained with the help of adaptive forecast models will enable enterprises to detect and prevent a crisis in a timely manner, which will enable to avoid bankruptcy. It is noted that among many methods of determining solvency and threats of bankruptcy there is no single universal, each method considers a certain aspect of financial and economic activity, therefore the best option is the application of several techniques for determining the threat of bankruptcy that complement each other.
\end{abstract}

Keywords: crisis, bankruptcy, crisis management, methods of bankruptcy diagnostics.

DOI: $10.32434 / 2415-3974-2019-9-1-125-129$

\section{Indroduction}

The transition of the Ukrainian economy is accompanied by instability and constant changes, which is known to have led to a systemic economic crisis in the country. Instability and the crisis situation in the economy negatively affects all spheres of social and economic life of the country. The activities of enterprises in a market economy are characterized by some degree of uncertainty and, accordingly, economic risk. Consequently, the question of timely diagnosis of bankruptcy of enterprises and the adoption of appropriate means of crisis management in a market environment requires fundamental research.

\section{The analysis of the research and publications}

Many scientific papers of domestic and foreign scientists are devoted to the problems of bankruptcy, rehabilitation and financial restructuring and their impact on the modern development of the Ukrainian economy, published a number of scientific and theoretical studies of domestic economists such as: Artemenko V.H., Bakanov M.I., Bellendir M.V., Blagodareva I.M., Voronova L.K., Danilov O.D., Ivashina H.M., Kachalov R.M., Kleiner G. B., Kovalev A.P, Krushevsky A.V, Lysenko Yu.G.,
Petrenko V.L., Tambovtsev V.L., Tereschenko O.O., Tkachenko A.M, Chumachenko O.G., Sheremet A.D. ets.

\section{The purpose of the article}

The purpose of this article is to structure the approaches to the diagnosis of bankruptcy of the subject of management.

\section{Main results}

The main feature of bankruptcy is the inability of the company to ensure that the claims of creditors are fulfilled within three months from the date of maturity.

The current state of development of methodical providing of diagnostics of the crisis situation and bankruptcy damages is characterized by a variety of approaches and tools for conducting them. Almost no study of foreign and domestic experts on anticrisis management can be done without specifying some of the methods that can be used to develop crisis prevention measures.

Several approaches are used to diagnose bankruptcy probabilities:

1. Conducting a comprehensive economic analysis of the subject of management.

2. Conduct an express analysis on a limited

(C) Pozhuieva T.O., 2019 
range of financial indicators.

3. Methods based on the integral assessment:

- scoring models;

- multivariate rating analysis;

- multiplicative discriminatory analysis.

Methods of forecasting the financial state of the enterprise.

Let consider each of the groups of methods in more detail.

Conducting a comprehensive economic analysis of the subject of management

Many domestic economists were engaged in the development of methods and techniques for a comprehensive analysis of the enterprise's business. The most successful method is presented in Fig. 1 [1].

All indicators, depending on the object of analysis, are grouped into such subsystems:

Indicators that make up the subsystem can be divided into incoming and outgoing, general and private ones. By means of input and output indicators interconnection of subsystems is carried out. The output of one subsystem is an indicator of input of another subsystem.

Thus, all indicators of economic activity of the enterprise are in close connection and dependence, which must be taken into account in the complex analysis. The relationship between the main indicators determines the sequence of analysis - from the study of primary indicators to generalizations. Such a sequence corresponds to the objective basis of the formation of economic indicators.

Each stage of the analysis requires appropriate research methods. In fig. 2 shows the classification of existing methods of economic analysis, in accordance with the works [2-6].

a) Logical methods are widely used in the general theory of statistics

Characteristic for logical methods is a creative understanding of the goals and principles of research,

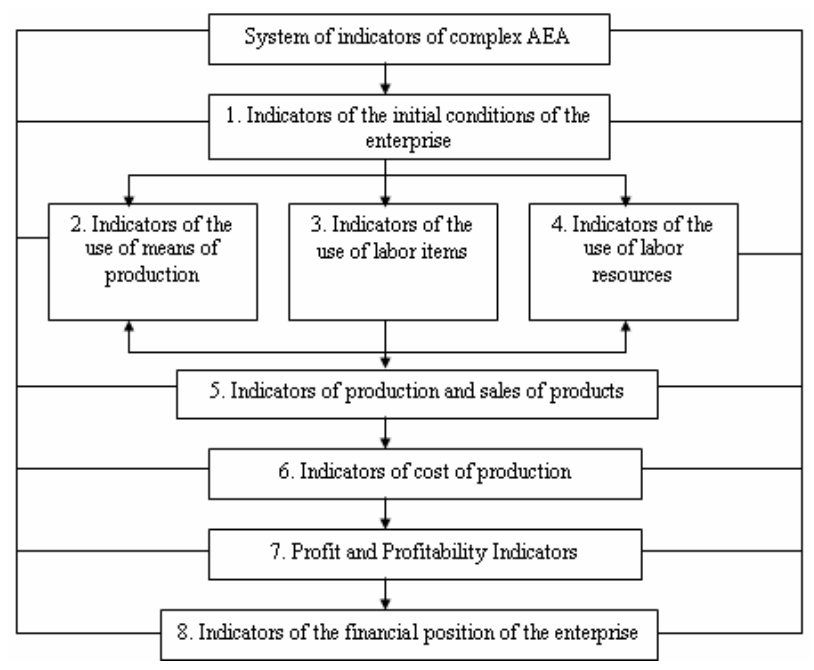

Fig. 1 System of indicators of complex AEA

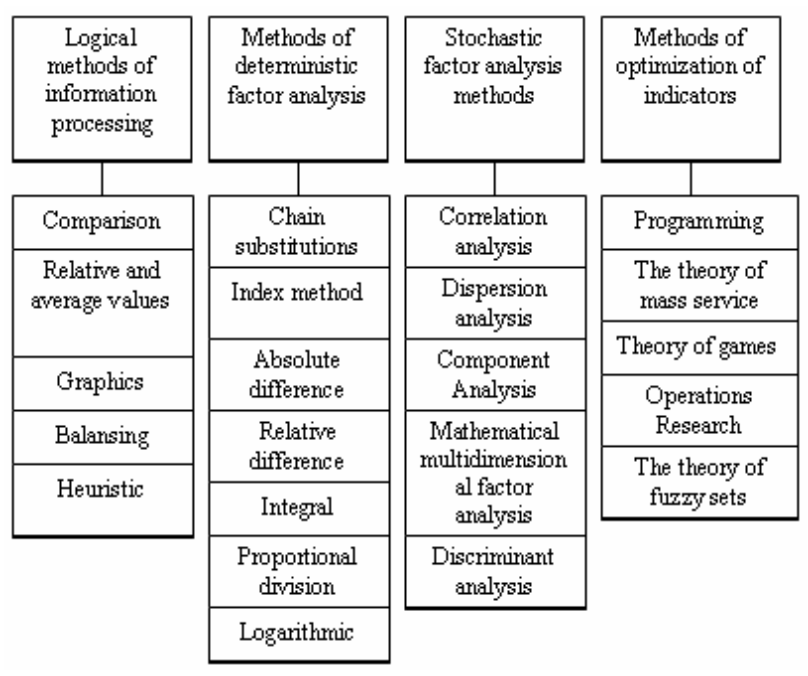

Fig. 2 Methods of analysis of economic activity of the enterprise

the application of the general scientific approach to the study of change and development of phenomena and processes through their division (differentiation) and synthesis (integration) and abstract approach. Abstraction is an important tool of any analytical study, since a large number of components, properties, aspects of phenomena and processes, as well as their connections can not be studied immediately. Investigating the influence of one factor, we must abstract from others. Splitting complex systems into elements allows you to know the internal structure and connections of change and development, and logical synthesis combines the results of the research, showing the object in a known form.

b) Deterministic factorial analysis is a method of studying the influence of factors, the relationship of which with the result is functional, that is, when the performance is presented in the form of product, private or sum, factor algebra

c) A stochastic analysis is aimed at the study of indirect connections, which can not be described by models of direct de-terminated communication. It acts as a tool for deepening deterministic analysis

Stochastic modeling of factor systems is based on generalization of the laws of fluctuation of the values of economic parameters and factors that influence them, that is, on the quantitative measurement of the probability of repeating the parameters of the same phenomenon in different conditions of a qualitatively homogeneous medium. The main purpose of stochastic modeling of factor systems is the choice of sufficiently correlated factors and the quantitative measurement of the probability of a functional connection.

d) Methods of optimization of indicators include methods of economical and mathematical modeling, based on a combination of economics, 
mathematics and information technology, which allows you to make optimal managerial decisions. These are methods such as: programming, the theory of mass service, game theory, operations research, the theory of fuzzy sets [7-11].

Each stage of analysis, rice. 1 implies the use of separate methods, that is, has its own method of conducting.

Conduct an express analysis on a limited range of financial indicators

In accordance with the current bankruptcy laws of enterprises to diagnose their insolvency, a limited range of indicators is used.

Modern economic science has a large number of various techniques and methods for forecasting financial indicators, including in terms of assessing possible bankruptcy.

Methods based on integral assessment

Given the variety of financial analysis indicators, the difference in the level of their critical assessments, many domestic and foreign economists recommend an integrated assessment of financial analysis based on scoring analysis. The method of credit scoring was first proposed by American economist D. Duran in the early 40 "s.

Scoring models categorize enterprises according to the degree of risk based on the actual level of indicators of financial stability and the rating of each indicator, expressed in points based on expert assessments (Table).

The first class includes enterprises with a sufficient margin of financial stability, which allows to be sure of the return of borrowed funds.

The second class includes enterprises with a certain degree of debt risk.

The third class includes problematic enterprises.

Up to the fourth class are enterprises with high risk of bankruptcy, even after taking measures for financial rehabilitation. $[12,13]$.

Until the fifth grade is the failure of enterprises

To assess the rating of economic entities and the degree of financial risk, the method of multidimensional rating analysis is often used.

In the international practice of assessing the probability of an insolvency of the business entity, the following multidimensional discriminating models have become widespread: Z-account of Altman, the model of Roman Lys, the predicted model of Tofler, the model of Springing, the Fulmer model, and J. Depalian's model [14].

Methods of forecasting the financial condition of the enterprise

The development of forecasting models of the financial state of an enterprise is necessary for the development of a general financial strategy for providing the company with financial resources, assessing its potential in the future. It should be based on the study of the real financial capabilities of the enterprise, internal and external factors and cover such issues as optimization of fixed and working capital, equity and debt capital, profit distribution, investment and pricing policies. The main attention is thus given to the identification and mobilization of internal reserves for increasing the cash income, the maximum reduction in the cost of production and services, the development of the correct policy of distribution of profits, the efficient use of enterprise capital at all stages of its circulation.

Usually, five methods of forecasting the financial condition of an entity are distinguished: extrapolation; method of terms of reversibility; method of budgeting; method of previous (forecast) balances; exponential smoothing models [15].

The use of forecast values of financial indicators, obtained using adaptive forecast models, will allow enterprises to detect and prevent a crisis in a timely manner, which will enable to avoid bankruptcy.

To sum it up, it should be noted that among many solvency and bankruptcy methods there is no single universal, each method deals with a certain aspect of financial and economic activity, so the best option is to use several techniques to identify the threat of bankruptcy that complement each other.

Grouping of enterprises into classes on the level of solvency

\begin{tabular}{c|c|c|c|c|c}
\hline \multirow{2}{*}{ Indicator } & \multicolumn{5}{|c}{ Class boundaries according to criteria } \\
\cline { 2 - 6 } & 1 class & 2 class & 3 class & 4 class & 5 class \\
\hline $\begin{array}{c}\text { Return on total } \\
\text { capital, \% }\end{array}$ & $\begin{array}{c}\text { Above } 30 \%- \\
50 \text { balls }\end{array}$ & $\begin{array}{c}\text { From } 29.9 \text { to } 20 \%- \\
\text { from } 49.9 \text { to } 35 \text { balls }\end{array}$ & $\begin{array}{c}\text { From } 19.9 \text { to } 10 \%- \\
\text { from } 34.9 \text { to } 20 \text { balls }\end{array}$ & $\begin{array}{c}\text { From } 9.9 \text { to } 1 \%- \\
\text { from } 19.9 \text { to } 5 \text { balls }\end{array}$ & Less $0 \%-0$ balls \\
\hline $\begin{array}{c}\text { Current liquidity } \\
\text { ratio }\end{array}$ & $\begin{array}{c}\text { Above } 2.0- \\
30 \text { balls }\end{array}$ & $\begin{array}{c}\text { From } 1.99 \text { to } 1.7- \\
\text { from } 29.9 \text { to } 20 \text { balls }\end{array}$ & $\begin{array}{c}\text { From } 1.69 \text { to } 1.4- \\
\text { from } 19.9 \text { to } 10 \text { balls }\end{array}$ & $\begin{array}{c}\text { From } 1.39 \text { to } 1.1- \\
\text { from } 9.9 \text { to } 1 \text { balls }\end{array}$ & Less $1-0$ balls \\
\hline $\begin{array}{c}\text { The coefficient } \\
\text { of financial } \\
\text { independence }\end{array}$ & $\begin{array}{c}\text { Above } 0.7- \\
20 \text { balls }\end{array}$ & $\begin{array}{c}\text { From } 0.69 \text { to } 0.45- \\
\text { from } 19.9 \text { to } 10 \text { balls }\end{array}$ & $\begin{array}{c}\text { From } 0.44 \text { to } 0.3- \\
\text { from } 9.9 \text { to } 5 \text { balls }\end{array}$ & $\begin{array}{c}\text { From } 0.29 \text { to } 0.2- \\
\text { from } 5 \text { to } 1 \text { balls }\end{array}$ & Less $0.2-0$ balls \\
\hline Limits classes & $\begin{array}{c}\text { Above } \\
100 \text { balls }\end{array}$ & From 99 to 65 balls & From 64 to 35 balls & From 34 to 6 balls & From 6 to 0 balls \\
\hline
\end{tabular}




\section{REFERENCES}

1. Bakanov M.I., Sheremet A.D. Theory of economic analysis. - Moskow: Finansy i statistika, 1999.

2. Kleiner H.B., Tambovtsev V.L., Kachalov R.M. Enterprise in the instable economic environment: risks, strategies, safety. Moskow: Ekonomika, 1997.

3. Kovaliov A.P. Diagnostic of bankraptcy. - Moskow: Finstatinform, 1995.

4. Sviatohor $O$. New view at the old problem. Statment of a moratorium on satisfaction of creditors' claims in bankruptcy cases // Yurydychnyi zhurnal - Legal journal. - 2004. - No. 5. - P.53-56.

5. Tereshchenko O.O. Financial rehabilitation and bankruptcy of enterprises. - Kyiv: KNEU, 2000.

6. Conditions for ensuring the financial sustainability of enterprises // Finansy Ukrainy - Finances of Ukraine. - 0000. - No. 8. - P.103-106.

7. Krushevskii A.V. Mathematics programming and modelling in economic. - Kiev: Vysshaia shkola, 1989.

8. Kuzin B., Yuriev V.. Shkhdinarov H. Methods and models of firm management. - Sankt-Peterburh: Piter, 2001.

9. Kundysheva Ye. Mathematic modelling in economic. Moscow: Dashkov i Ko, 2004.

10. Lysenko Yu.H., Petrenko V.L. Economic dynamics. Donetsk: Donetskyi derzhavnyi universytet, 2000.

11. Tkachenko A.M., Melnychuk V.P. Prevention of the threat of bankruptcy of an industrial enterprise // Ekonomichnyi visnyk ZDIA - Economic Bulletin ZSIA. - 2013. - No. 5. P.170-176.

12. Blahodareva I.M. Directory of the head of the industrial enterprise. - Moscow: Ekonomika, 1987.

13. Voronova L.K. Banking, financial and legal dictionary reference. - Kiev: A.S.K., 1998.

14. Artemenko V.H., Bellendir M.V. Financial analysis. Moscow: "DIS". 1997.

15. Danilov O.D., Ivashyna H.M., Chumachenko O.H. Organization and economic bases of investment. - Irpin: (n.d.), 2005.

Received 09.04.2019

Reviewer: Prof. Kolesnokov V.P.

\section{ДІАГНОСТИКИ КРИЗОВОГО СТАНУ ТА ЗАГРОЗИ БАНКРУТСТВА - ШЛЯХ ДО АНТИКРИЗОВОГО УПРАВЛІННЯ ПІДПРИЕМСТВОМ}

\section{Пожуєва T.O.}

Перехід економіки України супроводжується нестабільністю та постійними змінами, що, як відомо, призвело до системної економічної кризи в країні. Нестабільність та кризовий стан економіки негативно впливає на всі сфери суспільного та економічного життя країни. Діяльність підприємств в умовах ринкової економіки характеризується деякою мірою невизначеності та, відповідно, економічного ризику. Метою даноі статті є структурування підходів до діагностики банкрутства суб'єкта господарювання. У статті обгрунтовано, що використання прогнозних значень фінансових показників, отриманих за допомогою адаптивних прогнозних моделей дозволить підприємствам завчасно виявляти і попереджати кризу, що дасть змогу уникнути банкрутства. Зазначено, що серед багатьох методик визначення платоспроможності та загрози банкрутства не існує єдиної універсальної, кожна методика розалядає певний аспект фінансово-господарської діяльності, тому найкращим варіантом є застосування кількох методик визначення загрози банкрутства, які взаємодоповнюють одна одну.

Ключові слова: криза, банкрутство, антикризове управління, методи діагностики банкрутства.

\section{ДИАГНОСТИКИ КРИЗИСНОГО СОСТОЯНИЯ И УГРОЗЫ БАНКРОТСТВА - ПУТЬ К АНТИКРИЗИСНОМУ УПРАВЛЕНИЮ ПРЕДПРИЯТИЕМ}

\section{Пожуева Т.A.}

Переход экономики Украины сопровождается нестабильностью и постоянными изменениями, что, как известно, при вело к системного экономического кризиса в стране. Нестабильность и кризисное состояние экономики негативно влияет на все сферы общественной и экономической жизни страны. Деятельность предприятий в условиях рыночной экономики характеризуется некоторой степенью неопределенности $u$, соответственно, экономического риска. Целью данной статьи является структурирование подходов к диагностике банкротства предприятия. В статье обосновано, что использование прогнозных значений финансовых показателей, полученных $c$ помощью адаптивных прогнозных моделей позволит предприятиям заблаговременно выявлять и предупреждать кризис позволит избежсать банкротства. Отмечено, что среди многих методик определения платежеспособности и угрозы банкротства не существует единой универсальной, каждая методика рассматривает определенный аспект финансово-хозяйственной деятельности, поэтому лучшим вариантом является применение нескольких методик определения угрозы банкротства, которые взаимодополняют друг друга.

Ключевые слова: кризис, банкротство, антикризисное управление, методы диагностики банкротства. 


\section{CRISIS DIAGNOSTICS AND THE THREAT OF BANKRUPTCY RESEARCH - THE MAIN CRISIS MANAGEMENT WAY}

Pozhuieva T.O.

Ukrainian State University of Chemical Technology, Dnipro, Ukraine

* e-mail: lowleyhome@gmail.com

The transition of Ukraine's economy is accompanied by instability and constant changes, which is known to have led to a systemic economic crisis in the country. Instability and the crisis situation in the economy negatively affects all spheres of social and economic life of the country. The activities of enterprises in a market economy are characterized by some degree of uncertainty and, accordingly, economic risk. The purpose of this article is to structure the approaches to the diagnosis of bankruptcy of the subject of management. The article substantiates that the use of predictive values of financial indicators obtained with the help of adaptive forecast models will enable enterprises to detect and prevent a crisis in a timely manner, which will enable to avoid bankruptcy. It is noted that among many methods of determining solvency and threats of bankruptcy there is no single universal, each method considers a certain aspect of financial and economic activity, therefore the best option is the application of several techniques for determining the threat of bankruptcy that complement each other.

Keywords: crisis, bankruptcy, crisis management, methods of bankruptcy diagnostics.

\section{REFERENCES}

1. Bakanov M.I., Sheremet A.D. (1999). Teoria ekonomicheskoho analiza [Theory of economic analysis]. Moskow: Finansy i statistika [in Russian].

2. Kleiner H.B., Tambovtsev V.L., Kachalov R.M. (1997). Predpriiatie v nestabilnoi ekonomicheskoi srede: riski, stratehii, bezopasnost [Enterprise in the instable economic environment: risks, strategies, safety]. Moskow: Ekonomika [in Russian].

3. Kovaliov A.P. (1995). Diagnostyka bankrutstva [Diagnostic of bankraptcy]. Moskow: Finstatinform [in Ukrainian].

4. Sviatohor O. (2004). Novyi pohliad na staru problemu. Vstanovlennia moratoriiu na zadovolennia vymoh kredytoriv $\mathrm{u}$ spravi pro bankrutstvo [New view at the old problem. Statment of a moratorium on satisfaction of creditors' claims in bankrupt- cy cases]. Yurydychnyi zhurnal - Legal journal, 5, 53-56 [in Ukrainian].

5. Tereshchenko O.O. (2000). Finansova sanatsia ta bankrutstvo pidptyiestv [Financial rehabilitation and bankruptcy of enterprises]. Kyiv: KNEU [in Ukrainian].

6. Uslovia obespechenia finansovoi ustoichivosti predpriiatii [Conditions for ensuring the financial sustainability of enterprises]. Finansy Ukrainy - Finances of Ukraine, 8, 103-106 [in Russian].

7. Krushevskii A.V. (1989). Matemeticheskoie programmirovaniie i modelirovaniie $\mathrm{v}$ ekonomike [Mathematics programming and modelling in economic]. Kiev: Vysshaia shkola [in Russian].

8. Kuzin B., Yuriev V., Shkhdinarov H. (2001). Metody $i$ modeli upravletiia firmoi [Methods and models of firm management]. Sankt-Peterburh: Piter [in Russian].

9. Kundysheva Ye. (2004). Matematicheskoie modelirovaniie v ekonomike [Mathematic modelling in economic]. Moscow: Dashkov i Ko [in Russian].

10. Lysenko Yu.H., Petrenko V.L. (2000). Ekonomichna dynamika [Economic dynamics]. Donetsk: Donetskyi derzhavnyi universytet [in Ukrainian].

11. Tkachenko A.M., Melnychuk V.P. (2013). Poperedzhennia zahrozy bankrutstva promyslovoho pidpryiemstva [Prevention of the threat of bankruptcy of an industrial enterprise]. Ekonomichnyi visnyk ZDIA - Economic Bulletin ZSIA, 5, 170-176. Retrived from http://www.zgia.zp.ua/gazeta/ evzdia_5_170.pdf [in Ukrainian].

12. Blahodareva I.M. (1987). Spravochnik nachalnika tsekha promyshlennoho predpriiatia [Directory of the head of the industrial enterprise]. Moscow: Ekonomika [in Russian].

13. Voronova L.K. (1998). Bankovsko-finansovo-pravovoi slovar-spraavochnik [Banking, financial and legal dictionary reference]. Kiev: A.S.K. [in Russian].

14. Artemenko V.H., Bellendir M.V. (1997). Finansovyi analiz [Financial analysis]. Moscow: "DIS" [in Russian].

15. Danilov O.D., Ivashyna H.M., Chumachenko O.H. (2005). Orhanizatsiino-ekonomichni zasady investuvannia [Organization and economic bases of investment]. Irpin: (n.d.) [in Ukrainian]. 